DOI: $10.15290 /$ bsp.2018.23.02.06

Justyna Symber

Uniwersytet Gdański

justynasymber@gmail.com

ORCID ID: https://orcid.org/0000-0002-2705-5373

\title{
Opportunities and Threats of EU Regulatory Governance in the Energy Sector with Reference to Public Service Obligations - the President of the Energy Regulatory Office as a Regulatory Authority (a Case Study)
}

\begin{abstract}
The article focuses on the opportunities and threats of EU Regulatory Governance in the energy sector with reference to public service obligations. There are two pillars of regulation: the first being the independence of regulatory authorities, the second making decisions based on the state of competition. The article looks in depth at the discretionary power of the National Regulatory Authority - the President of the Energy Regulatory Office. It should be considered that National Regulatory Authorities have acquired a main role in the implementation of European Union law. Regarding this issue the article discusses the case pending before the District Court - Antimonopoly Court in Warsaw, case ref. no XVII AmE 93/13, dated 19 November 2013. In the view of the case XVII AmE 93/13, the systemic flaws of legal protection of energy enterprise are that the President of the Energy Regulatory Office is limited by the category of justified costs and the need for a reasonable return on the capital employed in this activity, while exercising statutory entitlement to verification of costs planned by the energy enterprise. Keywords: regulatory, energy, the President of the Energy Regulatory Office, National Regulatory Authority
\end{abstract}

\section{Introduction}

For the purpose of this work, the term "regulation" means a mode of making decisions by regulatory authorities predominantly in relation to infrastructure facilities. An independent regulatory authority makes decisions imposing regulatory obligations on enterprises in the energy sector, telecommunication, oil, gas and other infrastructural sectors. The main purpose of regulatory decisions is to balance the interests of infrastructure owners, other enterprises and consumers. 
Early versions of the Treaty of Rome made no references to regulated sectors. The Treaty of Maastricht ${ }^{1}$ introduced the notion of Trans-European Networks ${ }^{2}$, while the Treaty of Amsterdam ${ }^{3}$ introduced the Protocol on public broadcasters ${ }^{4}$. Currently, the following European Union legal foundations regarding regulatory governance are in force: Directive 2009/72/EC (internal market in electricity), Directive 2009/73/EC 6 (internal market in gas), Directive 2002/21/ $\mathrm{EC}^{7}$ (telecommunications - framework directive), Directive 2002/19/EC ${ }^{8}$ (telecommunications - access directive), Directive 2002/22/EC ${ }^{9}$ (telecommunications - universal services directive).

There are two pillars of regulation: the first being the independence of regulatory authorities, the second making decisions based on the state of competition ${ }^{10}$. In general, the following parties to regulation should be distinguished: National Regulatory Authorities (NRA), European Union regulators, and regulated enterprises.

In Poland, the President of the Energy Regulatory Office (the President of ERO) is the central body of government administration established under the Energy Law Act of 10 April1997 ${ }^{11}$, to carry out tasks in the field of fuel and energy management regulation and to promote competition. The responsibilities and competences of the President of ERO are closely related to state policy in the field of energy, i.e. the economic conditions involved in the functioning of energy enterprises, the concept of market functioning and requirements resulting from the obligation to adapt

1 Treaty of Maastricht on European Union, Official Journal C 191, 29/07/1992 pp. 0001-0110.

2 See: D. Johnson, C. Turner, Trans-European Networks, London 1997, p. 122.

3 Treaty of Amsterdam amending the Treaty on European Union, the Treaties establishing the European Communities and certain related acts - Final Act, Official Journal C 340, 10/11/1997 p. 0115.

4 See: I. Katsirea, Public Broadcasting and European Law: A Comparative Examination of Public Service Obligations in Six Member States, Alphen aan den Rijn 2008, p. 325.

5 Directive 2009/72/EC of the European Parliament and of the Council of 13 July 2009 concerning common rules for the internal market in electricity and repealing Directive 2003/54/EC, Official Journal of the European Union L 211/55.

6 Directive 2009/73/EC of the European Parliament and of the Council of 13 July 2009 concerning common rules for the internal market in natural gas and repealing Directive 2003/55/EC (Text with EEA relevance), Official Journal of the European Union L 211/94.

7 Directive 2002/21/EC of the European Parliament and of the Council of 7 March 2002 on a common regulatory framework for electronic communications networks and services (Framework Directive), Official Journal L 108, 24/04/2002 pp. 00330050.

8 Directive 2002/19/EC of the European Parliament and of the Council of 7 March 2002 on access to, and interconnection of, electronic communications networks and associated facilities (Access Directive), Official Journal L 108, 24/04/2002 pp. 0007-0020.

9 Directive 2002/22/EC of the European Parliament and of the Council of 7 March 2002 on universal service and users' rights relating to electronic communications networks and services (Universal Service Directive), Official Journal L 108, 24/04/2002 pp. 0051-0077.

10 See: F. Gilardi, M. Maggetti, The independence of regulatory authorities, Zurich 2010, pp. 1-21.

11 The Act of April 10, 1997 - Energy Law, Journal of Laws 2017, item 220. 
Opportunities and Threats of EU Regulatory Governance in the Energy Sector...

Polish law to the law of the European Union ${ }^{12}$. Currently, the competences of the President of ERO arising from Article $23 \mathrm{sec} .2$ of the Energy Law Act, include the following activities: cooperation with regulatory authorities of the Member States of the European Union, informing the European Commission about the designation of transmission system operators or concluding agreements with the regulatory authorities of other European Union Member States ${ }^{13}$.

\section{Public service obligation}

According to Article $16 \mathrm{TEC}^{14}$, "given the place occupied by services of general economic interest in the shared values of the Union as well as their role in promoting social and territorial cohesion, the Community and the Member States, each within their respective powers and within the scope of application of this Treaty, shall take care that such services operate on the basis of principles and conditions which enable them to fulfil their missions." Moreover, Article 106 TEC states that, "undertakings entrusted with the operation of services of general economic interest or having the character of a revenue-producing monopoly, shall be subject to the rules contained in this Treaty, in particular to the rules on competition, in so far as the application of such rules does not obstruct the performance, in law or in fact, of the particular tasks assigned to them" 15 and, "the development of trade must not be affected to such an extent as would be contrary to the interests of the Community."

In the context of European Union law, a public service obligation (PSO) is an obligation imposed on an organisation by legislation or contract to provide a service of general interest within the territories of the European Union. PSOs may operate in any field of public service such as postal services, social services, energy, transport and banking.

In view of the foregoing, particular attention needs to be paid to the regulations contained in PSO Directive 2003/54/EC ${ }^{16}$ and PSO Directive 2009/72/EC.

According to Article 3 \$1 PSO Directive 2003/54/EC, "Members States may impose on undertakings operating in the electricity sector, in the general economic

12 See: M. Rejmus, Zadania Prezesa Urzędu Regulacji Energetyki a polityka energetyczna państwa, Poznań 2014, pp. 123-125.

13 See: P. Wroniecki, Kompetencje Prezesa Urzędu Regulacji Energetyki na gruncie wybranych regulacji ustawowych, Kraków 2015, pp. 40-46.

14 Treaty Establishing the European Community, Official Journal C 340, 10/11/1997 p. 0173 Consolidated version.

15 See: K. Dougan, Blackstone's UK \& EU Competition Documents, Glasgow 2015, p. 223.

16 Directive 2003/54/EC of the European Parliament and of the Council of 26 June 2003 concerning common rules for the internal market in electricity and repealing Directive 96/92/EC, Official Journal of the European Union L 176/57. The Directive 2003/54/EC has been replaced by the Directive 2009/72/EC. 
interest, public service obligations which may relate to security, including security of supply, regularity, quality and price of supplies and environmental protection, including energy efficiency and climate protection". Also in Article $3 \mathrm{sec} .8$ of PSO Directive 2009/72/EC it is said that, "Member States may decide not to apply the provisions of Articles 6, 7, 20 and 22 insofar as their application would obstruct the performance, in law or in fact, of the obligations imposed on electricity undertakings in the general economic interest; and insofar as the development of trade would not be affected to such an extent as would be contrary to the interests of the Community".

Member States may impose, in the general economic interest, public service obligations which may relate to: "security, including security of supply, regularity, quality and price of supplies and environmental protection, including energy efficiency, energy from renewable sources and climate protection" (Article $3 \$ 1$ of PSO Directive 2003/54/EC). Such obligations must be precisely defined, translucent, non-discriminatory, verifiable and shall guarantee equality of access for electricity undertakings of the Community to national consumers ${ }^{17}$. In relation to security of supply, energy efficiency/demand-side management and for the fulfilment of environmental goals and goals for energy from renewable sources, states may introduce the implementation of long-term planning, taking into account the possibility of third parties seeking access to the system.

Article $3 \$ 8$ of PSO directive 2009/72/EC, statues that "in order to promote energy efficiency, Member States or, where a Member State has so provided, the regulatory authority shall strongly recommend that electricity undertakings optimise the use of electricity, for example by providing energy management services, developing innovative pricing formulas, or introducing intelligent metering systems or smart grids, where appropriate."

Taking all into account, it might be said that the potential scope of public obligations is extremely wide. Public service obligations are an accepted issue in the infrastructural sectors of Member States. The importance of PSOs may vary but they prevail over competition rules.

\section{Discretionary power of the National Regulatory Authority}

The discretionary powers of regulatory authorities mirror the precarious position of infrastructural enterprises. What is more, National Regulatory Authority may define their markets according to local circumstances. According to Article $15 \$ 3$ of Directive 2002/21/EC, "National regulatory authorities shall, taking the utmost account of the recommendation and the guidelines, define relevant markets 
appropriate to national circumstances, in particular relevant geographic markets within their territory, in accordance with the principles of competition law".

It should be considered that National Regulatory Authorities have acquired a main role in the implementation of European Union law. National Regulatory Authority are established by the Member States, implying that they are part of the national administrative organisation chart. Their formation, however, is mandatory under European Union law ${ }^{18}$. Today's National Regulatory Authority acquire most of their competences from European Union legislation, even if the formal legal basis of their tasks is generally the national legislation that implements the European Union directives.

\section{Case study: District Court - Antimonopoly Court in Warsaw, case ref. no XVII AmE 93/13, dated 19 November 2013)}

By decision on 6 October 2016 the President of ERO, acting under Article 155 $\mathrm{CAP}^{19}$, Article $47 \mathrm{sec} .1$ and sec. 2 in connection with Article $30 \mathrm{sec} .1$ and Article 45 of the Energy Law Act, refused to amend the distribution energy tariff as submitted by distribution enterprise 'P'. 'P' established a tariff on energy distribution. The tariff was later approved by the Regulator on 17 December 2009. The procedure of making the tariff was also approved by the Regulator. On 2 June 2010, enterprise 'P' filed for the amendment of the tariff under art. 155 CAP. The proposed tariff increased prices by $5,4 \%$ on grounds that some of the cost of distribution was not going to be covered by the previous tariff.

In June and September 2010, enterprise 'P' filed for another increase of the tariff anticipating a further increase in the price of electricity. The predicted average purchase price of energy would be 187,52 PLN/MWh, or $170 \mathrm{PLN} / \mathrm{MWh}$ per unit in January-March 2010. The President of ERO declared that the tariff change would result in $3,68 \%$ increase in consumer prices (for the first tariff amendment). The second motion to increase the tariff would result in a further $3,47 \%$ increase and together the two motions would lead to an $8,84 \%$ increase. In the President of ERO's view, the fundamental importance has to be attached to the question of whether the conditions provided for in Article 155 of CAP have been satisfied ${ }^{20}$ in the spirit of Article 23 of the Energy Law Act, mandating the President of ERO to balance the

18 See: S. De Somer, The independence of national regulatory authorities: required by EU law, illreceived by national constitutional law, http://www.osservatorioair.it/the-independence-ofnational-regulatory-authorities-required-by-eu-law-ill-received-by-national-constitutional-law/ (access 2.01.2018).

19 The Act of 14 June 1960 Code of Administrative Procedure, consolidated text Journal of Laws 2017, item 1257, further referred as CAP.

20 According to Article 155 CAP the final decision by which a party has acquired the right may at any time with the consent of the party be revoked or amended by the public administration 
conflicting interests. According to the President of ERO, the premise of justified interest of the party has not been satisfied. It is not true, as claimed by ' $\mathrm{P}$ ', that the 2009 and 2010 tariffs had been calculated in violation of Article 45 section 1 and 2 of the Energy Law, that is they do not cover the justified cost borne by enterprise " $\mathrm{P}$ ". It is reasonable to assess the profit of an enterprise in view of its general financial reports for its activity in energy distribution is its main activity, the other two activities being of a subsidiary nature. The reports for 2010 have shown profit. This constitutes a proof that revenues under the tariff were capable of covering the justified cost of distribution and the justified return on capital. That return is defined as gross profit and is not part of the cost. The very fact that enterprise ' $\mathrm{P}$ ' has achieved profit indicates 'P's' capital is rewarded - there is a return on capital. To approve 'P's' motions would amount to a further increase of profitability. It is a role of the President of ERO to balance the interest of energy enterprises and of consumers under Article $23 \mathrm{sec}$. 2 pt $3 c$ of the Energy Law. According to enterprise 'P' the plan of supplies for 2009 has not been achieved, which means that buyers were affected, directly or indirectly, by the crisis. Therefore, in the President of ERO's view, further deterioration of the financial condition of buyers struggling with the crisis means that the first premise of Article 155, i.e. public interest, has not been met. It is not in the public interest to follow with two price increases. Also, the increase would have triggered inflation and a general increase in prices. Two price increases in a short time make it impossible to plan spending by public entities, enterprises and households. The President of ERO indicated that prices for 2010 should not be higher than 170 PLN/MWh, because such a price allows to cover the justified cost and earn profit. There is an increase in gross sales and profitability by $13 \%$ to $19 \%$ with different energy sellers compared to 2008. No changes took place in the market to justify a price increase. Decisions to buy energy are independent decisions of an enterprise, and their business risk, particularly that $87,78 \%$ of the energy bought by enterprise ' $\mathrm{P}$ ' was purchased from its own subsidiary which facilitates renegotiation of the contract.

In the President of ERO's view, there is no justified interest of enterprise ' $\mathrm{P}$ ' for such an interest cannot be interpreted as avoidance of business risk. In the appeal, enterprise ' $\mathrm{P}$ ' applied for:

- amendment of the President of ERO's decision and approval of the new tariff as proposed by enterprise ' $\mathrm{P}$ ' in subsequent motions,

- in case of adjudication after the expiration of the tariff - repealing of the President of ERO's decision with a statement that the President of ERO's refusal to approve tariff change as proposed by 'P' has not been justified.

body that issued it, if the specific provisions do not preclude the revocation or revision of such a decision and there is a social interest or party's legitimate interest. 


\section{Systemic flaws of energy enterprise legal protection}

In the light of case XVII AmE 93/13, the systemic flaws of energy enterprise legal protection lay in the fact that the President of the ERO is limited by the category of justified costs $^{21}$ and the need for a reasonable return on the capital employed in this activity $^{22}$, while exercising statutory entitlement to the verification of costs planned by the energy enterprise.

According to Article $3 \mathrm{sec} .21$ of the Energy Law Act, justified costs are defined as the necessary costs to meet the obligations incurred by an energy company engaged in the generation, processing, storage, transmission and distribution of fuels or energy, and accepted by the energy company for the calculation of prices and tariff rates in an economically feasible manner justified with due diligence aimed at protecting the interests of the public.

According to Article $45 \mathrm{sec}$. 1 pt. 1-3 of the Energy Law Act, energy enterprises shall set tariffs for gaseous fuels or energy, in accordance with the scope of the economic activity referred to in Article $32 \mathrm{sec} .1$ of the Energy Law Act. The tariffs shall be calculated in such way as to:

- cover the costs of legitimate business activity of the energy enterprise in the production, processing, transmission, distribution or trading of gaseous fuels and energy and the storage, liquefying or regasification of gaseous fuels together with a justified return on the capital employed in this activity,

- cover the costs of legitimate business activities of the energy enterprise in the field of gaseous fuel storage, including the construction, expansion and modernisation of gaseous fuel storage facilities, together with a reasonable return on the capital employed in this activity, of not less than a $6 \%$ return rate,

- cover justified costs borne by transmission and distribution system operators in the performance of their tasks,

- protect the interests of consumers against unjustified price levels and fees.

Article 45 of the Energy Law Act is an expression of the implementation into Polish law of European Union directives regulating the energy and fuels market, consistently striving to prevent the use of its economic advantage by energy companies while ensuring them a fair return of capital ${ }^{23}$.

Tariff decisions of the President of ERO cannot expose the energy enterprise to operating at a loss, whereas, by law, it must provide a reasonable profitability provided that the revenue is maintained at the level of costs justified with a justified return from

21 Article $3 \mathrm{sec} .21$ of the Energy Law Act.

22 Article $45 \mathrm{sec} .1$ pt. 1 of the Energy Law Act.

23 See: B. Bednarski, Komentarz do art. 45 Prawa energetycznego, (in:) M. Kuliński, Prawo energetyczne. Komentarz, Warszawa 2017, p. 731-734. 
the capital involved in this business. Article $45 \mathrm{sec} .1$ of the Energy Law Act, aims to reconcile the interests of an energy company and, on the other hand, to protect the interests of consumers against unjustified price levels ${ }^{24}$. The core of Article 45 of the Energy Law Act, consists of the following rules:

- rules for ensuring the coverage of the costs of justified energy activities while guaranteeing the protection of consumers against unjustified tariff levels,

- the possibility to include in the tariff the cost of co-financing environmental investments and investment in energy efficiency improvement, as well as

- the criterion of cost of performance as the sole factor of price differentials and charges to customers.

The appeal of the party against the decision of the President of ERO is in essence the nature of the action and initiates proceedings from the beginning and on the basis of adversarial proceedings. The purpose of court proceedings is not to conduct administrative proceedings, but the merits of the case, which is the subject of a dispute between the parties arising only after the decision of the President of ERO.

Pursuant to the decision of the Supreme Court ${ }^{25}$, it is ultimately up to the Court to apply the relevant standard of substantive law, on the basis of an explanation of the factual basis, covering all the factual elements foreseen in the hypothesis of that norm. Otherwise, it cannot be argued that the substantive law was correctly applied.

Proceedings before the Antimonopoly Court may be initiated only after exhaustion of administrative proceedings before the President of ERO. There can be used evidence gathered in administrative proceedings, but it is generally limited to the fact that administrative proceedings are a condition of admissibility of the court and that in court proceedings antimonopoly court exercises not only legality control, but also the validity of the decision issued by the President of ERO.

Consequently, the Antimonopoly Court is obliged to comprehensively investigate all relevant circumstances of the case, taking into account the principles of the burden of proof and the obligation of the parties to the proceedings. It should not be forgotten that the appeal process is very long in practice, which in turn obliges an energy enterprise to apply an approved tariff until the new proceedings are completed. Moreover, it should be noted that the elements of tariff building itself are subject to the rigors indicated by the President of the ERO, in particular in terms of electricity purchase prices and the rate of return (for distribution system operators).

24 See: M. Czarnecka, Komentarz do art. 45 Prawa energetycznego, (in:) M. Czarnecka, T. Ogłódek, Prawo energetyczne. Komentarz, Warszawa 2012, p. 620.

25 Supreme Court, case ref. no I CKN 1234/00, dated on 28 June 2002; Supreme Court, case ref. no. I CC 81/0, dated on 18 September 2003. 


\section{Court's reasoning and arguments}

In principle, the Court's reasoning and arguments are justified in the settled case-law. The Court referred to the ruling of the Supreme Court, which ruled that under Article $45 \mathrm{sec}$. 1 of the Energy Law Act, a tariff must be calculated solely on the basis of justified cost and justified return. The Energy Law Act does not define "capital return" so this has to be borrowed from economics where it refers to "source of income". Under Article $45 \mathrm{sec} .1$ pt 1 of the Energy Law Act, only the capital engaged in that specific activity can be taken into account when calculating the tariff. Therefore, the President of ERO is empowered to see whether the calculation takes into account solely the assets closely connected with the given activity ${ }^{26}$. What is more, according to the Supreme Court ${ }^{27}$ a tariff can be amended if regulatory actions addressed to other market players caused changes in the elements of the cost on the part of the plaintiff.

Moreover, the plaintiff has a right to invoke the general principles of Article 45 of the Energy Law Act, however it misses the fact that it is up to the energy company to set up the tariff, even though the enterprise should not bear negative consequences of adjusting the tariff to regulatory expectations. The later remark would work only if the plaintiff managed to demonstrate that consumer interest should not be in the way of setting realistic prices, particularly if it was miscalculated to the detriment of the energy enterprise ${ }^{28}$. Although, the facts presented in this case, allow me to disagree with the principles of "capital return".

One of the basic principles of conducting business activity is the lack of admissibility, coverage of the costs of one type of business activity or costs related to one group of recipients of revenue from another type of business activity or from another group of customers. In this context, it can be stated that the reasoning given by the Court in the justification of the assumption of "combining operating costs" with all the activities carried out by the energy company by the licensed company, where they have ancillary character, is incorrect. I am not convinced by the fact that the financial assessment of economic activity "in the field of electricity distribution is based on reports prepared for total activity".

In addition, in the justification of the case, there is also information on the economic crisis and its consequences, among others. For the plaintiff decrease in electricity supply. In this regard, this could lead to a lack of fixed costs, but in the absence of detailed financial data in this area, it is not possible to reliably confirm to what extent this reduction in the value of capital was compared to the planned value.

26 A. Kisielewicz, Sądowa kontrola administracji w sprawach gospodarczych, Warszawa 2013, p. 171.

27 Supreme Court Resolution of 15 June 2004, III SZP 2 / 04, dated on 15 June 2004.

28 Supreme Court, case ref. no III SK 37/10, dated on 9 March 2011. 


\section{Conclusion}

The crucial requirement regarding the regulatory design, in the EU legislation on the common market for energy, is that the regulators should be independent of commercial interests in the sector ${ }^{29}$. The above analysis of case XVII AmE 93/13, shows that the discretionary power of the National Regulatory Authority - the President of the Energy Regulatory Office, while exercising statutory entitlement to the verification of costs planned by the energy enterprise, is limited by the category of justified costs and the need for a reasonable return on the capital employed in this activity.

The energy enterprise should make a forecast of energy purchase prices based on its own knowledge and experience. In this context, it is irrelevant to use the tariffs published by the President of the ERO, as these data are not binding and only serve as an "indicator" when preparing the tariff for approval. The financial effect of the contract concluded occurs in the cost of running the business. There is no definitive justification for the view that the cost of doing business should be fully transferred to entities such as the final consumer. Contracts for trading electricity are subject to economic risk. In practice, this translates to both loss and profitability.

Moreover, the court rulings ${ }^{30}$ indicate that a change of tariff is allowed if, as a result of actions addressed to other market participants by the regulator, the cost components of an enterprise requesting a tariff increase are used to change the decision approving it. Likewise, the interests of electricity consumers alone should not in principle block the possibility of price realisation, particularly where the premise for doing so has been wrongly established and could harm the energy company ${ }^{31}$.

It is assumed in the judicial decisions that, despite the need to ensure stability of turnover through an annual tariff, it is necessary to respect the statutory rules of Article $45 \mathrm{sec} .1$ of the Energy Law Act. A tariff calculated below the justified costs of the seller represents an advantage to the recipients as they receive the product at a discounted price. This advantage becomes unauthorized if it is obtained outside the vendor's risk limits, as a result of the administrative structure of the tariff setting.

There are no circumstances in the present case that would allow the application of Article 155 CAP. The legitimate interest of a party within the meaning of Article 155 CAP, could only happen if the party was able to demonstrate a change in the market environment as a result of intervention by the President of ERO. It should be noted that at the time of submitting the application for tariff approval, enterprise ' $\mathrm{P}$ ' knew the purchase price of electricity, while in the period between the approval of the tariff and the submission of new requests for a change of tariff under Article $155 \mathrm{CAP}$,

29 P. Capros, Independence of energy regulators: new challenges, Athens 2003, p. 3.

30 Supreme Court Resolution of 15 June 2004, III SZP 2 / 04, dated on 15 June 2004.

31 Supreme Court Resolution of 15 June 2004, III SZP 2 / 04, dated on 15 June 2004. 
there were no "exceptional circumstances" justifying a new application for a change of tariff.

\section{BIBLIOGRAPHY}

Bednarski B., Komentarz do art. 45 Prawa energetycznego, (in:) M. Kuliński, Prawo energetyczne. Komentarz, Warszawa 2017.

Capros P., Independence of energy regulators: new challenges, Athens 2003.

Czarnecka M., Komentarz do art. 45 Prawa energetycznego, (in:) M. Czarnecka, T. Ogłódek, Prawo energetyczne. Komentarz, Warszawa 2012.

De Somer S., The independence of national regulatory authorities: required by EU law, ill-received by national constitutional law, http://www.osservatorioair.it/the-independence-of-nationalregulatory-authorities-required-by-eu-law-ill-received-by-national-constitutional-law/ (access 2.01.2018).

Dougan K., Blackstone’s UK \& EU Competition Documents, Glasgow 2015.

Gilardi F., Maggetti M., The independence of regulatory authorities, Zurich 2010.

Katsirea I., Public Broadcasting and European Law: A Comparative Examination of Public Service Obligations in Six Member States, Alphen aan den Rijn 2008.

Kim T., Introduction to EU Energy Law, Oxford 2016.

Kisielewicz A., Sądowa kontrola administracji w sprawach gospodarczych, Warszawa 2013.

Rejmus M., Zadania Prezesa Urzędu Regulacji Energetyki a polityka energetyczna państwa, Poznań 2014.

Wroniecki P., Kompetencje Prezesa Urzędu Regulacji Energetyki na gruncie wybranych regulacji ustawowych, Kraków 2015. 